\title{
ANOMALI EFEK KALENDER PADA RETURNSAHAM LQ-45 DI BURSA EFEK INDONESIA
}

\author{
Komang Intan Permatasari ${ }^{1}$ \\ I Ketut Mustanda ${ }^{2}$
${ }^{1,2}$ Fakultas Ekonomi dan Bisnis Universitas Udayana (Unud), Bali, Indonesia e-mail: blissintan@gmail.com

\begin{abstract}
ABSTRAK
Anomali efek kalender mengindikasikan adanya penyimpangan return di suatu pasar modal yang memungkinkan investor untuk memanfaatkan suatu waktu dan memperoleh abnormal return. Penelitian ini bertujuan untuk mengetahui perbedaan rata-rata abnormal returnpada hari perdagangan (the day of the week effect), hari senin minggu keempat (week-four effect), serta bulan Januari dengan bulan lainnya (January effect). Penelitian dilakukan pada perusahaan yang masuk dalam kelompok saham LQ-45 dan didapat sampel berjumlah 35 perusahaan dengan menggunakan metode sampel jenuh. Sumber data berasal dari data sekunder melalui website yahoo finance dan metode pengumpulan data dilakukan dengan observasi non partisipan meliputi pengumpulan data perkembangan harga saham yang masuk dalam kelompok LQ-45 selama periode Februari 2015 sampai dengan Januari 2018.Hasil pengujian dengan program SPSS melalui uji Kruskal Wallis dan Uji Mann Whitney, menunjukkan bahwa rata-rata abnormal returnsaham pada setiap waktu tidak berbeda, sehingga mendapatkan kesimpulan bahwa tidak terjadi the day of the week effect, week-four effect, dan January effect pada indeks saham LQ-45 di Bursa Efek Indonesia.
\end{abstract}

Kata kunci: anomali efek kalender, abnormalreturn

\begin{abstract}
Calendar effect anomalies indicate a return deviation in a capital market that allows investors to take advantage of a time and obtain abnormal returns. This study aims to determine the difference in the average abnormal return on the day (the day of the week effect), Monday the fourth week (week-four effect), and January with other months (January effect). The study was conducted on companies included in the LQ-45 stock group and obtained a sample of 35 companies using the saturated sample method. The data source comes from secondary data, through the yahoo finance website and the method of data collection is done by non-participant observation including data collection on the development of stock prices included in the LQ-45 group during the period February 2015 to January 2018. Test results with the SPSS program through Kruskal-Wallis test and Mann Whitney Test, show that the stock's average abnormal return at any time is not different, so the conclusion that there is no day of the week effect, week-four effect, and January effect on the LQ-45 stock index on the Stock Exchange Indonesia.
\end{abstract}

Keywords: calendar effect anomaly, abnormal return 


\section{PENDAHULUAN}

Pasar modal adalah salah satu financial market yang merupakan wadah perdagangan instrument investasi dan modal, yang dapat dimanfaatkan untuk memobilisasi dana. Setiap orang yang terlibat dalam pasar modal, khususnya investor akan berusaha dan mengharapkan return dari kegiatan perdagangan yang dilakukan. Salah satu cara untuk mencapai return yang optimal di pasar modal adalah dengan melakukan analisis pasar modal, yang menggunakan pendekatan analisis teknikal maupun fundamental. Analisis dapat dilakukan oleh investor itu sendiri ataupun menggunakan jasa dari analis pasar modal seperti broker, dealer dan manajer investasi untuk menganalisa perilaku perdagangan saham. Salah satu cara agar seseorang mampu menghasilkan dana untuk memenuhi kebutuhannya adalah dengan melakukan investasi. Investor yang menanamkan dananya berarti telah mengorbankan kebutuhan lainnya, sehingga mereka pasti mengharapkan suatu timbal balik yang lebih besar atau setidaknya sama dengan dana yang ditanamkan.

Pasar modal dasarnya harus bersifat efisien agar menarik untuk tempat bertransaksi. Setiap pihak yang terlibat dalam transaksi pasar tentunya ingin mendapatkan manfaat atau keuntungan dari kegiatan perdagangan. Hipotesis pasar efisienberasumsi bahwa seluruh pelaku pasar sudah mampu mengolah informasi yang masuk secara cermat dan berhati-hati serta rata-rata informasi yang dimiliki oleh para pelaku pasar adalah benar, sehingga investor merasa kegiatan perdagangan di pasar modal sudah berlangsung secara adil tanpa ada salah satu investor yang mampu mendapatkan lonjakan return yang tidak wajar. Pasar modal 
Komang Intan Permatasari dan I Ketut Mustanda, Anomali Efek Kalender Pada...

yang efisien adalah pasar di mana harga semua sekuritas yang diperdagangkan telah mencerminkan semua informasi yang tersedia secara cepat dan tepat. (Tandelilin, 2010:219). Konsep pasar efisien menyiratkan adanya suatu proses penyesuaian harga sekuritas menuju harga keseimbangan yang baru, sebagai respons atas informasi baru yang masuk ke pasar. Informasi dalam pasar modal datangnya tidak dapat diprediksi, sehingga reaksi yang terjadi dalam pasar modal juga mengalami pola yang sama, karena pasar akan bergerak ketika informasi datang. Begitu cepatnya respon pasar terhadap penyampaian informasi dalam pasar modal, sehingga tidak memungkinkan bagi investor untuk memperoleh abnormal return. (Fauzi, 2007 ; Latif, 2011).

Perdagangan di pasar modal yang sangat sensitif dan banyaknya pihak yang ikut terlibatmemungkinkan timbulnya penyimpangan (anomali) pada pasar modal efisien. Suatu pasar dikatakan mengalami anomali, ketika pasar saham tersebut mengalami reaksi atas kejadian yang tidak termasuk ke dalam konsep pasar efisien (Cahyaningdyah dan Witiastuti, 2010). Anomali ini mengindikasikan adanya penyimpangan returnpada saham yang terdapat di pasar modal. Terjadinya anomali di suatu pasar modal memungkinkan investor untuk mendapatkan abnormalreturn, yang seharusnya tidak mungkin terjadi apabila pasar tersebut berbentuk efisien. Salah satu anomali yang sering diperbincangkan adalah anomali efek kalender.

Anomali yang banyak mendapatkan perhatian adalah anomali efek kalender. Anomali efek kalender terjadi karena waktu tertentu menghasilkan lonjakan return secara sistematis dan konsisten dibandingkan dengan waktu yang lain. 
Terdapat dua tipe seasonalities yaitu (1) High Frequency Seasonality contohnya The Day of The Week Effect, The Turn of The Month Effect dan (2) The Low Frequency Seasonality yaitu January Effect (Xiao, 2016).TheDay of The Week Effectadalah fenomena yang terjadi apabila hari perdagangan di pasar modal dalam seminggu memiliki perbedaan returndi setiap harinya. Week-Four Effect mengungkapkan bahwa return negatif di hari Senin hanya terjadi pada minggu keempat untuk setiap bulannya.January Effect menunjukkan terdapat kecenderungan bahwa keuntungan saham akan menurun pada bulan Desember dan kemudian akan meningkat pada bulan Januari.

Iramani dan Mahdi (2006) melakukan penelitian terhadap the day of the week effectterhadap return saham di Bursa Efek Jakarta, menggunakan tiga puluh delapan perusahaan sebagai sampel yang masuk dalam kelompok saham LQ-45 periode Januari-Desember 2005. Hasil penelitian tersebut menyatakan terdapat pengaruh hari perdagangan (Day of The Week Effect) dan pengaruh senin minggu keempat akhir (Week Four Effect) di Bursa Efek Indonesia. Didapatkan hasil bahwa rata-rata return hari Jumat bernilai positif dan mempunyai rata-rata return tertinggi. Hasil yang sama mengenai rata-rata returntertinggi pada hari Jumat juga didapatkan oleh Soareset al. (2013) yang melakukan penelitian mengenai the day of the week effect dari tahun 1994-2011 di Brazilian Stock Market pada indeks Ibovespa dan Kohli (2014) yang melakukan penelitian dari tanggal 27 Agustus 1987 sampai dengan 12 Oktober 2012 pada pasar tembaga dan aluminium. Selain itu Nugrohoet al. (2017) yang melakukan penelitian mengenai the day of the week effect dan week-four effect di indeks LQ-45 selama 18 periode dari Februari 2007 
Komang Intan Permatasari dan I Ketut Mustanda, Anomali Efek Kalender Pada...

sampai dengan Januari 2016. Nugroho et al. (2017) menemukan adanya fenomena the day of the week effect pada indeks saham LQ-45, namun tidak menemukan adanya fenomena week-four effect. Roseliani dan Khairunnisa (2015), menemukan adanya fenomena the day of the week effect dan week-four effect pada perusahaan LQ-45 yang terdaftar di Bursa Efek Indonesia periode 2013.

Patel, Radadia dan Dhawan (2012)melaksanakan penelitian di empat pasar saham padakawasan negara Asia yaitu: Bombay, Hong Kong, Tokyo dan Shanghai Stock Exchange. Bombay Stock Exchangemenghasilkanreturn rata-rata maksimumdi hari Rabu dengan penyimpangan tertinggi di hari Senin. Pada tahun 2014, Dragota, Tilica dan Opreamelaksanakan penelitian untuk menganalisis apakah hari perdagangan mempengaruhi return saham di pasar modal Bucharest. Metode yang digunakan adalah regresi dengan variabel dummy dan dari penelitian iniditemukan adanya Friday Effect, rata-rata returnharian Jumat lebih tinggi dibandingkan dengan hari lainnya. Saraswatiet al. (2015) melakukan penelitian terhadap return saham pada indeks LQ-45 di Bursa Efek Indonesia dan mendapatkan hasil bahwa terjadi peristiwathe day of the week effect dan week-four effect pada 41 saham aktif CHITIN lisitng di indeks LQ-45 selama periode 2013.

Fitriyani dan Sari (2013) yang melakukan penelitian mengenai January Effectpada indeks LQ-45 antara tahun 2009-2011 dan mendapatkan hasil bahwaEfek Januari terjadi di Bursa Efek Indonesia. Pradnyaparamita dan Rahyuda (2017) juga melakukan penelitian mengenai January Effect pada indeks LQ-45 di Bursa Efek Indonesia, menemukan hasil bahwa terjadi January Effect pada indeks saham LQ-45 di Bursa Efek Indonesia selama periode Februari 2009 
sampai dengan Januari 2014. Hal tersebut kemudian berbanding terbalik dengan hasil penelitian yang didapatkan oleh Cahyaningdyah dan Putra (2013) yang melakukan penelitian pada 30 perusahaan yang secara kontinu masuk indeks saham LQ-45 selama periode 2011-2012, bahwa tidak terjadi January Effect pada indeks LQ-45 di Bursa Efek Indonesia. Sari dan Sisdayani (2013)juga melakukan penelitian mengenai January Effect di Bursa Efek Indonesia selama periode 2012 yang menyebutkan bahwa di Pasar Modal Indonesia tidak terjadi January Effect. Penelitian dari Osmelia (2016)di Bursa Efek Indonesia selama periode 2007-2014 juga tidak menemukan adanya fenomenaJanuary Effect di Bursa Efek Indonesia periode 2007-2014 baik di returnmaupun abnormal return.

Adapun rumusan permasalahan dalam penelitian ini adalah apakah terdapat anomali pasar hari perdagangan, senin minggu keempat dan bulan perdagangan, sehingga tujuan dari penelitian ini adalah untuk menguji coba dan menganalisis terjadinya anomali efek kalender pada indeks saham LQ-45 di Bursa Efek Indonesia. Penelitian ini diharapkan dapat memberikan manfaat terhadap seluruh pihak terkait baik secara langsung, maupu tidak langsung. Diharapkan nantinya hasil pengkajian ini bisa memberikan memberikan kontribusi empiris pada ilmu manajemen keuangan dan sumbangan pemikiran mengenai anomali pasar efisien terhadap abnormal return secara teoretis. Secara praktis hasil penelitian ini diharapkan dapat memberikan masukan bagi investor dan menjadi bahan pertimbangan strategi transaksi jual beli saham agar dapat memperoleh return yang maksimal dan wajar.

Pada saat melakukan investasi, ada tahap-tahap keputusan investasi yang 
Komang Intan Permatasari dan I Ketut Mustanda, Anomali Efek Kalender Pada...

berjalan terus-menerus sampai tercipta keputusan investasi yang terbaik. Tahaptahap keputusan tersebut, yaitu : (1) Penentuan Tujuan Investasi (2)Penentuan KebijakanInvestasi

Tahap ini dimulai dengan proses penentuan keputusan alokasi aset yang menyangkut pendistribusian dana yang dimiliki oleh investor pada berbagai kelas aset yang ada.(1) Pemilihan StrategiPortofolio, dalam memilih strategi portofolio, investor bisa memilih dua tipe strategi yaitu antara strategi portofolio aktif dan pasif. Apabila ingin menggunakan strategi portofolio aktif, kegiatan yang dilakukan investor meliputi penggunaan informasi yang tersedia dan teknik peramalan secara aktif untuk bisa menemukan kombinasi portofolio yang paling baik. Sementara pada strategi portofoliopasif, investor bisa membeli reksadana. (2) PemilihanAset, pada tahap ini berlangsung proses evaluasi setiap sekuritas yang ingin dimasukkan dalam portofolio. Tujuannya adalah untuk mendapatkan kombinasi portofolio yang efisien.Portofolio yang efisien menawarkan returndiharapkan yang tinggi dengan tingkat risiko tertentu atau sebaliknya. (3) Pengukuran dan Evaluasi KinerjaPortofolio, tahap pengukuran dan evaluasi kinerja ini meliputi pengukuran kinerja portofolio dan perbandingan hasil tersebut dengan kinerja portofolio lainnya melalui proses benchmarking, untuk mengetahui seberapa baik kinerja portofolio yang telah ditentukan dibandingkan dengan kinerja portofolio lainnya.

Saham adalah tanda kepemilikan seseorang atau instansi terhadap suatu perusahaan yang menerbitkan surat berharga tersebut berupa selembar kertas (Tandelilin, 2010). Dari hak yang melekat pada saham, saham terbagi menjadi dua 
jenis yaitu :Saham biasa (common stock) menyatakan kepemilikan suatu perusahaan. pemilik saham biasa akan mendapatkan dividen apabila perusahaan menghasilkan laba dalam menjalankan bisnisnya, sebagian atau seluruh laba dapat dibagikan kepada pemilik yang bersangkutan. Namun pembagian dan besarnya dividen belum tentu terjamin, dari tahun ke tahun bisa berubah-ubah. Bisa lebih tinggi daripada sebelumnya, lebih rendah bahkan tidak dibagikan oleh perusahaan. Saham preferen merupakan jenis ekuitas yang hampir sama dengan saham biasa, yang membedakan adalah dividen yang dibayarkan berjumlah tetap dan tidak pernah berubah. Selain itu pemilik saham preferen akan mendapatkan dividen lebih dulu daripada pemilik saham biasa.

Returnsaham adalah timbal balik yang diterima oleh investor atas keputusannya menanamkan modal pada perusahaan tertentu (Jogiyanto, 2010:195). Returnmencerminkan kondisi suatu saham, saat returnyang diperoleh tinggi maka kemungkinan besar saham tersebut berada dalam kondisi yang baik, sebaliknya bila return bernilai rendah maka saham tersebut berada dalam kondisi yang kurang baik.

Abnormal returnmerupakan selisih returnyang diharapkan dengan returnyang didapatkan sesungguhnya (Jogiyanto, 2010:195). Abnormal returnbisa bernilai positif dan negatif, berarti bisa berbentuk keuntungan maupun kerugian. Selisih returnakan bernilai positif jika returnyang diterima lebih besar dari returnyang diharapkan. Sedangkan returnakan negatif jika returnyang diterima lebih kecil dari returnyang diharapkan.

Awalnya indeks ini dibentuk berdasarkan kondisi pasar saham yang jarang 
Komang Intan Permatasari dan I Ketut Mustanda, Anomali Efek Kalender Pada...

terjadi transaksi, sehingga saham-saham yang aktif ditransaksikan dalam kelompok tersebutdigabung menjadi satu. Pertimbangan dipilihnya saham untuk masuk ke dalam kelompok saham ini tidak hanya berpedoman pada likuiditas yang tinggi melainkan juga pada besar kecilnya kapitalisasi pasar.

Hipotesis pasar efisien menyiratkan adanya proses penyesuaian harga sekuritas menuju harga keseimbangan baru sebagai respons atas informasi baru yang masuk ke pasar. Hal terpenting dalam proses penyesuaian harga ini adalah, tidak terbentuknya harga yang bias agar bisa mencerminkan nilai intrinsic yang sesungguhnya dari suatu pasar. Harga akan terbentuk setelah investor menilai dampak yang bisa disebabkan dari informasi tersebut.

Anomali pasar adalah teknik atau strategi yang tidak sejalan dengan konsep pasar model efisien. Fenomena yang terjadi akan sangat berlawanan dan akan ditemukan hal yang seharusnya tidak ada biladianggap bahwa pasar efisien benarbenar ada. Seorang investor bisa memanfaatkan suatu peristiwa (event) untuk memperoleh lonjakan return yang tidak normal apabila dalam suatu pasar modal terjadi fenomena anomali.

\section{METODE PENELITIAN}

Penelitian ini merupakan penelitian komparatifyang bersifat membandingkan. Penelitian ini ditujukan untuk mengungkapkan dan menganalisis fenomena-fenomena yang ada pada abnormalreturn saham-saham LQ-45 di Bursa Efek Indonesia mengenai anomali pasar efisien. Penelitian dilakukan pada indeks saham LQ-45 selama periode Februari 2015 sampai dengan Januari 2018. Objek dalam penelitian ini adalah saham pada indeks LQ-45 yang secara kontinu muncul 
selama periode Februari 2015 sampai dengan Januari 2018. Variabel yang digunakan yaitu abnormal returnsaham pada setiap waktu. Rumus menghitung abnormal return menggunakan metode Market Adjusted Model (Jogiyanto,2010:580):

$$
\text { ARit }=\text { Rit }- \text { Rmt }
$$

\section{Keterangan:}

ARit = abnormal return saham i pada hari ke $\mathrm{t}$

Rit = actual return saham i pada hari ke $\mathrm{t}$

Rmt $=$ Return pasar

Populasi dalam penelitian ini adalah saham-saham LQ-45 di Bursa Efek Indonesia yang secara kontinu muncul pada periode Februari 2015 sampai dengan Januari 2018. Penarikan sampel menggunakan metode sampel jenuh, sehingga didapatkan sampel sebanyak 35 perusahaan. Terdapat dua jenis data yang digunakan yaitu data kuantitatif yang berupa perkembangan harga saham yang masuk dalam kelompok saham LQ-45 dan data kualitatif yaitu hari dan bulan perdagangan. Sumber data yang digunakan berasal dari sumber sekunder yaitu website Yahoo Finance.

Metode pengumpulan data yang digunakan dalam penelitian ini adalah melalui observasi non partisipan meliputi pengumpulan data perkembangan harga saham yang masuk dalam kelompok LQ-45. Teknik analisis data dilakukan dengan menggunakan uji statistik non parametrik yaitu Uji Kruskal Wallis dan Uji Mann Whitney U, karena data tidak terdistribusi dengan normal.

\section{HASIL DAN PEMBAHASAN}


Komang Intan Permatasari dan I Ketut Mustanda, Anomali Efek Kalender Pada...

Indeks LQ 45 merupakan salah satu indeks di Bursa Efek Indonesia (BEI), dimana indeks tersebut diperoleh dari perhitungan 45 emiten dengan seleksi kriteria seperti penilaian atas likuiditas. Berikut adalah 35 sampel emiten yang selama enam periode masuk ke dalam indeks saham LQ-45 secara kontinu:

Tabel 1.

Profil Singkat Sampel

\begin{tabular}{|c|c|c|c|}
\hline No & Kode & Nama Emiten & Tanggal Listing \\
\hline 1 & AALI & Astro Agro Lestari & 09-Des-1997 \\
\hline 2 & ADHI & Adhi Karya Tbk & 18-Mar-2004 \\
\hline 3 & ADRO & Adaro Energy Tbk & 16-Jul-2008 \\
\hline 4 & AKRA & AKR Corporindo Tbk & 03-Okt-1994 \\
\hline 5 & ASII & Astra International Tbk & 04-Apr-1990 \\
\hline 6 & $\mathrm{BBCA}$ & Bank Central Asia Tbk & 31-Mei-2000 \\
\hline 7 & BBNI & Bank Negara Indonesia Tbk & 25-Nop-1996 \\
\hline 8 & BBRI & Bank Rakyat Indonesia Tbk & 10-Nop-2003 \\
\hline 9 & BBTN & Bank Tabungan Negara Tbk & 17-Des-2009 \\
\hline 10 & BMRI & Bank Mandiri Tbk & 14-Jul-2003 \\
\hline 11 & BSDE & Bumi Serpong Damai Tbk & 06-Jun-2008 \\
\hline 12 & GGRM & Gudang Garam Tbk & 27-Ags-1990 \\
\hline 13 & ICBP & Indofood CBP Sukses Makmur Tbk & 7-Oct-2010 \\
\hline 14 & INCO & Vale Indonesia Tbk & 16-Мay-1990 \\
\hline 15 & INDF & Indofood Suksses Makmur Tbk & 14-Jul-1994 \\
\hline 16 & INTP & Indocemet Tunggal Prakasa Tbk & 05-Des-1989 \\
\hline 17 & JSMR & Jasa Marga Tbk & 12-Nop-2007 \\
\hline 18 & KLBF & Kalbe Farma Tbk & 30-Jul-1991 \\
\hline 19 & LPKR & Lippo Karawaci Tbk & 28-Juni-1996 \\
\hline 20 & LPPF & Matahari Department Store Tbk & 9-Oct-1989 \\
\hline 21 & LSIP & PP London Sumatera Indonesia Tbk & 5-Jul-1996 \\
\hline 22 & MNCN & Media Nusantara Citra Tbk & 22-Jun-2007 \\
\hline 23 & PGAS & Perusahaan Gas Negara Tbk & 15-Des-2003 \\
\hline 24 & PTBA & Tambang Batubara Bukit Asem Tbk & 23-Des-2002 \\
\hline 25 & PTPP & PP Tbk & 09-Feb-2010 \\
\hline 26 & PWON & Pakuwon Jati Tbk & 9-Oct-1989 \\
\hline 27 & SCMA & Surya Citra Media Tbk & 16-Jul-2002 \\
\hline 28 & SMGR & Semen Indonesia Tbk & 08-Jul-1991 \\
\hline 29 & SMRA & Summarecon Agung Tbk & 7-Mei-1990 \\
\hline 30 & SSMS & Sawit Sumbermas Sarana Tbk & 12-Dec-2014 \\
\hline 31 & TLKM & Telekomunikasi Indonesia Tbk & 14-Nov-1995 \\
\hline 32 & UNTR & United Tractors Tbk & 19-Sep-1989 \\
\hline 33 & UNVR & Unilever Indonesia Tbk & 11-Jan-1982 \\
\hline 34 & WIKA & Wijaya Karya & 29-Okt-2007 \\
\hline 35 & WSKT & Waskita Karya & 19-Des-2012 \\
\hline
\end{tabular}

Sumber:Yahoo Finance, 2018

Saham yang dianalisis berjumlah 35 saham di indeks LQ 45 pada periode penelitian Februari 2015 sampai dengan Januari 2018. Pada Tabel 2 dipaparkan 
deskripsi abnormal return saham harian untuk semua saham yang digunakan dalam penelitian ini.

Tabel 2.

Deskripsi Abnormal ReturnHarian Saham

\begin{tabular}{lccccc}
\hline & $\mathbf{N}$ & Minimum & Maximum & Mean & Std. Deviation \\
\hline Senin & 134 & $\mathbf{- . 0 2 7 1 9 4}$ & .012606 & $\mathbf{- . 0 0 0 5 9 8 1 6}$ & .005262652 \\
Selasa & 142 & -.016236 & $\mathbf{. 5 4 2 0 2 9}$ & .00374248 & $\mathbf{. 0 4 5 7 2 0 9 9 6}$ \\
Rabu & 144 & -.009903 & .024688 & .00084287 & .005120511 \\
Kamis & 136 & -.011050 & .024231 & .00030870 & .005045198 \\
Jumat & 135 & -.009978 & .010838 & -.00037036 & .003841287 \\
\multicolumn{1}{c}{ Total } & 691 & -.027194 & .542029 & .00081713 & .021172288 \\
\hline
\end{tabular}

Sumber : Data diolah, 2018

Tabel 2. menunjukkan bahwa jumlah setiap harinya berbeda-beda dari rentang 134 sampai dengan 144 hari. Perbedaan hari yang terjadi ini disebabkan karena perdagangan saham di pasar modal juga dipengaruhi oleh hari libur. Sehingga banyak hari yang hilang dalam 6 periode karena pasar modal tidak beroperasi. Rata-rataabnormal return terendah terjadi pada hari Senin, dimana abnormal return menunjukkan nilai negatif sebesar -0.00059816. di hari setelahnya yaitu Selasa, terjadi kenaikan abnormal return yang cukup tajam dimana return meningkat menjadi 0.00374248 dan merupakan rata-rata abnormal return tertinggi. Kemudian terjadi penurunanabnormal return pada hari Rabu, Kamis, dan Jumat menjadi 0.00084287, 0.00030870, dan -0.00037036. Nilai penyimpangan terbesar terjadi pada hari Selasa 0.045720996. Ini mengindikasikan bahwa Selasa memilik nilai risiko tertinggi dibandingkan hari lainnya. Risiko hari Jumat memiliki nilai standar deviasi yang paling kecil jika dibandingkan dengan hari lainnya yang menandakan bahwa hari Jumat memiliki risiko paling kecil, nilai standar deviasi terendah yaitu sebesar 0.003841287 . 
Komang Intan Permatasari dan I Ketut Mustanda, Anomali Efek Kalender Pada...

Normalitas suatu data diuji dengan menggunakan statistik nonparametrik yaitu metode uji satu sampel Kolmogorov-Smirnov. Dari hasil pengujian normalitas data tersebut, didapat hasil sebagai berikut:

\section{Tabel 3.}

Uji Normalitas The Day of The Week Effect

One-Sample Kolmogorov-Smirnov Test

Abnormal return

$\mathbf{N}$

Normal Parameters ${ }^{\text {a.b }}$

Most Extreme Differences

Test Statistic

Asymp. Sig. (2-tailed)

Sumber: Data diolah, 2018

\section{Mean}

Std. Deviation

Absolute

Positive

Negative
691

.00081713

.021172288

.323

.323

$-.309$

.323

$.000^{\mathrm{c}}$

Olahan data dengan menggunakan SPSS terlihat bahwa probabilitas penerimaan Ho sebesar 0.000, atau lebih kecil dari taraf signifikansi sebesar 0,05. Hal ini berarti bahwa data abnormal return saham harian tidak memiliki sebaran yang baik dan normal, sehingga penelitian harus dilanjutkan dengan menggunakan uji nonparametrik yaitu Uji Kruskal-Wallis.

Hipotesis pertama dalam penelitian ini adalah bahwa terjadi the day of the week effect pada indeks LQ-45 di Bursa Efek Indonesia yang menyebabkan perbedaan return harian rata-rata yang didapat dalam seminggu. Sebaran data yang tidak berdistribusi normal menyebabkan pengujian hipotesis selanjutnya dilaksanakan dengan menggunakan uji non parametrik yaitu Uji Kruskal Wallis. Hasil uji dipaparkan dalam Tabel 4 :

Tabel 4.

Hasil Uji Kruskal Wallis The Day of The Week Effect

Hari Mean Rank Abnormal 


\begin{tabular}{|c|c|c|c|c|c|}
\hline & Perdagangan & & & & return \\
\hline \multirow[t]{6}{*}{ Abnormal return } & Senin & 134 & 327.99 & Chi-Square & 4.765 \\
\hline & Selasa & 142 & 352.73 & Df & 4 \\
\hline & Rabu & 144 & 373.66 & Asymp.Sig. & .312 \\
\hline & Kamis & 136 & 341.47 & & \\
\hline & Jumat & 135 & 331.85 & & \\
\hline & Total & 691 & & & \\
\hline
\end{tabular}

Sumber : Data diolah, 2018

Tabel 4 menunjukkan bahwa nilai tingkat signifikansi yang diperoleh adalah 0.312 yang lebih besar daripada tingkat signifikansi $0.05(0.312>0,05)$. Ini mengindikasikan bahwa Ho dalam penelitian tidak dapat ditolak (diterima). Hipotesis pertama dalam penelitian ini ditolak karena pada hasil penelitian menunjukkan bahwa tidak terdapat perbedaan abnormal return saham selama lima hari perdagangan. Ini berartihari perdagangan tidak berdampak terhadap abnormal return saham di indeks LQ-45 BEI periode Februari 2015 sampai dengan Januari 2018.

Hari Senin memang memiliki rata-rata abnormal returnterendah pada penelitian ini, namun perbedaannya dengan hari lain tidak signifikan. Rata-rata abnormal returnterendah yang memiliki nilai negative, terjadi pada hari Senin. Abnormal returnterendah yang terjadi di hari Senin ini kemungkinan besar bisa diakibatkan oleh banyaknya investor yang masih mengkaji berbagai informasi yang relevan di hari Senin dan sedang melakukan penentuan strategi untuk bertransaksi di hari selanjutnya. Pada hari Senin, investor hanya mengantongi informasi di minggu sebelumnyan karena informasi yang tersedia biasanya masih merupakan informasi yang sudah lama,. Sementara di akhir minggu investor tidakselalu menerima informasi yang berhubungan dengan sekuritas saham yang 
Komang Intan Permatasari dan I Ketut Mustanda, Anomali Efek Kalender Pada...

dimilikinya. Kalaupun ada informasi yang masuk, itu merupakan isu-isu saja yang sifatnya hanya perkiraan dan kebenarannya belum tentu bisa dijamin.

Minimnya informasi menyebabkan investor memiliki kekhawatiran yang tinggi dan cenderung melakukan penjualan atas saham yang dimiliki daripada melakukan transkasi pembelian. Hal ini lah yang mungkin menjadi penyebab rendahnya harga saham di hari Senin dibandingkan hari perdagangan lainnya. Alhasil return saham yang didapatkan pun menjadi rendah bahkan bernilai negatif. Aktivitas perdagangan saham akan selalu berubah setiap harinya. Salah satu penyebabnya adalah perbedaan faktor-faktor psikologis pada investor setiap hariyang ikut mempengaruhi perasaan optimisme dan pesimisme investor tersebut.

Penelitian ini sejalan dengan penelitian dari Bachtiar (2009) yang melakukan penelitian pada indeks saham LQ-45 dan non LQ-45, menemukan hasil bahwa tidak terjadi fenomena the day of the week effect pada indeks LQ-45 di Bursa Efek Indonesia. Dari hasil penelitian ini disimpulkan bahwa tidak terjadi anomali pasar hari perdagangan pada 35 perusahaan sampel di indeks saham LQ45 karena tidak ada perbedaan rata-rata abnormal returnyang signifikan pada hari perdagangan.

Tabel 5.

Deskripsi Abnormal ReturnSenin Minggu Awal dan Senin Minggu Akhir

\begin{tabular}{lccccc}
\hline & N & Minimum & Maximum & Mean & $\begin{array}{c}\text { Std. } \\
\text { Deviation }\end{array}$ \\
\hline Senin123 & 90 & -.01187 & .01187 & -.0000861 & .00475408 \\
Senin45 & 43 & -.02719 & .01261 & -.0015585 & .00614387 \\
Total & 134 & -.02719 & .01261 & -.0005622 & .00526565 \\
\hline Sumber $:$ Data diolah, 2018 & & & &
\end{tabular}


Berdasarkan Tabel 5dipaparkan jumlah data yang digunakan untuk menguji dan menganalisis terjadinyaweek-four effect. Hanya data abnormal return saham pada hari Senin selama 6 periode yang digunakan pada uji coba ini. Jumlah hari Senin minggu ke-1,2,3 dan minggu ke 4,5 selama periode penelitian sebanyak 134 hari.

Tabel 5 menunjukkan bahwa Senin Minggu 1,2 dan 3 memiliki rata-rata abnormal return -0.0000861 dengan standar deviasi 0.00475408. Pada hari Senin minggu ke-4 dan 5, memiliki rata-rata abnormal return -0.0015585 dengan standar deviasi 0.00614387 . Standar deviasi yang lebih besar dari nilai rata-rata berarti bahwa sebaran data tergolong kurang baik dan terlalu bervariasi (heterogen). Berikut adalah hasil uji normalitas week-four effect :

Tabel 6.

Uji Normalitas Week-Four Effect

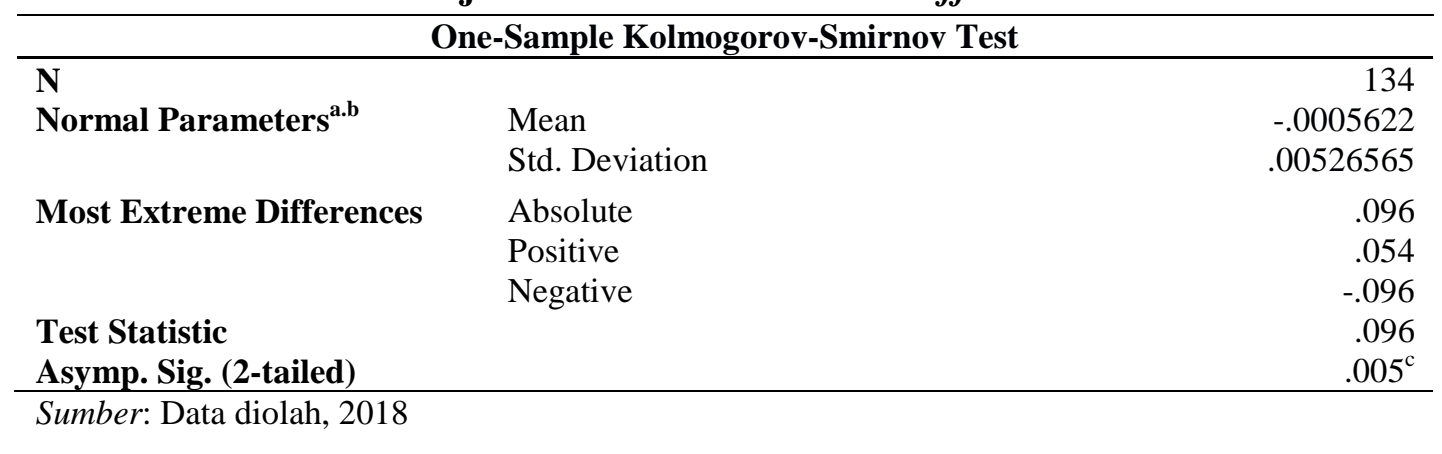

Olahan data dengan menggunakan SPSS terlihat bahwa probabilitas penerimaan Ho sebesar 0.000, atau lebih kecil dari taraf signifikansi sebesar 0,05. Hal ini berarti bahwa data abnormal return saham hari Senin tidak tersebar secara normal, sehingga penelitian harus dilanjutkan dengan menggunakan uji nonparametrik yaitu Uji Mann-Whitney U. Pengujian dilakukan dengan cara membandingkan abnormal return minggu terakhir dengan abnormal return hari 
Komang Intan Permatasari dan I Ketut Mustanda, Anomali Efek Kalender Pada...

Senin pada minggu awal yaitu pertama sampai ketiga. Pengujian dilakukan menggunakan Uji Mann-Whitney $U$.

Hipotesis kedua dalam penelitian ini adalah bahwa terjadi fenomenaweek four effect pada indeks LQ-45 di Bursa Efek Indonesia yang menyebabkan perbedaan return Senin minggu pertama sampai ketiga dengan Senin minggu keempat dan kelima. Pengujian hipotesis ini dilakukan dengan menggunakan Uji Mann-Whitney $U$ karena datanya tidak terdistribusi normal. Hasilnya diringkas dalam Tabel 7 :

Tabel 7.

Hasil Uji Mann-Whitney U Week Four Effect

\begin{tabular}{llllll}
\hline & Senin ke & N & Mean Rank & Sum of Ranks & \\
\hline Abnormal return & Senin Awal & 90 & 69.74 & 6277.00 \\
& Senin Akhir & 43 & 61.26 & 2634.00 & \\
& Total & 134 & & & .235 \\
\hline
\end{tabular}

Berdasarkan Tabel 7 dalam uji Mann-Whitney di atas, menyatakan bahwa nilai signifikansi sebesar $0.235>0.05$ yang berarti bahwa Ho tidak dapat ditolak (diterima). Hasil uji ini menjelaskan bahwa tidak terdapat perbedaan signifikan antara abnormal return hari Senin minggu ke-4 atau 5 dengan hari Senin minggu ke-1 sampai 3 pada indeks saham LQ-45 di Bursa Efek Indonesia periode Februari 2015-Januari 2018. Dengan demikian pada periode Februari 2015 sampai dengan Januari 2018 pada indeks LQ-45 di Bursa Efek Indonesia, tidak terjadi efek minggu keempat (week four effect) abnormal return saham.

Perbedaan rata-rata abnormal returnminggu awal dan minggu akhir samasama memiliki nilai negatif. Walaupun begitu perbedaannya tidak signifikan. Tidak terjadinya fenomena week-four effect dapat disebabkan karena tuntutan 
likuiditas investor tidak mempengaruhi perdagangan di indeks LQ-45. Minggu keempat atau kelima dalam bulan perdagangan bisa dikatakan menjadi minggu dimana investor memiliki banyak kebutuhan namun belum bisa meningkatkan penghasilannya. Hal ini dikarenakan banyaknya perusahaan dan instansi yang membagikan gaji, honor, dan upah pada awal bulan. Investor terutama investor kecil, diakhir bulan ini cenderung akan melakukan penjualan saham untuk memenuhi kebutuhannya. Namun, kondisi ini tidaklah sama dengan yang terjadi di Amerika dimana banyak investor kecil yang berinvestasi sehingga tuntutan likuiditasnya pada akhir bulan menjadi hal penting yang menggerakkan perdagangan di bursa. Kemungkinan investor individu yang memiliki tuntutan likuiditas di akhir bulan, tidak terlalu banyak bertransaksi pada saham-saham yang tergabung pada indeks LQ-45 di Bursa Efek Indonesia.

Penelitian ini sejalan dengan Rita (2009) yang tidak menemukan pengaruh minggu keempat di Bursa Efek Indonesia. Dari hasil penelitian ini disimpulkan bahwa tidak terjadi anomali pasar Senin minggu keempat pada 35 perusahaan sampel di indeks saham LQ-45 karena tidak ada perbedaan rata-rata abnormal returnyang signifikan pada senin minggu kesatu sampai ketiga dengan senin minggu keempat dan kelima.

Berdasarkan Tabel 8 dapat dilihat bahwa bulan September memiliki ratarata abnormal return tertinggi yaitu 0.023045 sementara bulan November memiliki rata-rata abnormal return terendah yaitu -0.15742 . Bulan Januari memiliki rata-rata abnormal return yang tinggi yaitu sebesar 0.004608 , namun tidak sebesar bulan September. Berikut uji normalitas January effect: 
Tabel 8.

Deskripsi Abnormal ReturnBulanan

\begin{tabular}{cccccc}
\hline & N & Minimum & Maximum & Mean & Std. Deviation \\
\hline Januari & 3 & -.0036 & .0178 & .004608 & .0115715 \\
Februari & 3 & -.0166 & .0324 & .000525 & .0276675 \\
Maret & 3 & -.0142 & .0001 & -.007604 & .0072323 \\
April & 3 & -.0184 & .0218 & .000735 & .0201872 \\
Mei & 3 & -.0302 & .0207 & -.008712 & .0263566 \\
Juni & 3 & .0003 & .0199 & .010405 & .0098001 \\
Juli & 3 & -.0156 & -.0051 & -.009983 & $\mathbf{. 0 0 5 2 9 0 0}$ \\
Agustus & 3 & -.0437 & .0244 & -.011909 & .0342785 \\
September & 3 & -.0041 & .0472 & $\mathbf{. 0 2 3 0 4 5}$ & .0257797 \\
Oktober & 3 & -.0301 & .0874 & .017114 & $\mathbf{. 0 6 2 0 1 9 4}$ \\
November & 3 & $\mathbf{- . 0 4 5 8}$ & .0133 & $\mathbf{- . 0 1 5 7 4 2}$ & .0295591 \\
Desember & 3 & -.0063 & .0512 & .013272 & .0328631 \\
\hline Total & 36 & -.0458 & .0874 & .001313 & .0266370 \\
\hline
\end{tabular}

Sumber: Data diolah, 2018

Tabel 9.

Uji Normalitas January Effect

\begin{tabular}{|c|c|c|}
\hline \multicolumn{3}{|c|}{ One-Sample Kolmogorov-Smirnov Test } \\
\hline $\mathbf{N}$ & & 36 \\
\hline \multirow{2}{*}{ Normal Parameters ${ }^{\text {a.b }}$} & Mean & .001313 \\
\hline & Std. Deviation & .0266370 \\
\hline \multirow[t]{3}{*}{ Most Extreme Differences } & Absolute & .181 \\
\hline & Positive & .181 \\
\hline & Negative & -.118 \\
\hline Test Statistic & & .181 \\
\hline Asymp. Sig. (2-tailed) & & $.004^{\mathrm{c}}$ \\
\hline
\end{tabular}

Sumber: Data diolah, 2018

Berdasarkan olahan data dengan menggunakan SPSS terlihat bahwa probabilitas penerimaan Ho sebesar 0.004, atau lebih kecil dari taraf signifikansi sebesar 0,05 . Hal ini berarti bahwa data abnormal return saham bulanan tidak berdistribusi normal, sehingga penelitian harus dilanjutkan dengan menggunakan uji nonparametrik yaitu Uji Kruskal Wallis.

Pengujian dilakukan dengan cara membandingkan abnormal returnbulan Januari dengan bulan lainnya selama 6 periode. Hasil pengujian yang dilakukan menggunakan Uji Kruskal Wallis. 
Tabel 10.

Hasil Uji Kruskal Wallsis January Effect

\begin{tabular}{lcccll}
\hline & $\begin{array}{c}\text { Hari } \\
\text { Perdagangan }\end{array}$ & N & Mean Rank & $\begin{array}{l}\text { Abnormal } \\
\text { return }\end{array}$ \\
\hline Abnormal & Januari & 3 & 23.00 & Chi-Square & 8.435 \\
Return & Februari & 3 & 17.00 & Df & 11 \\
& Maret & 3 & 16.33 & Asymp.Sig. & .674 \\
April & 3 & 18.67 & & \\
Juni & 3 & 25.67 & & \\
Juli & 3 & 13.33 & & \\
& Agustus & 3 & 13.67 & & \\
September & 3 & 28.33 & & \\
Oktober & 3 & 18.67 & & \\
& November & 3 & 12.33 & & \\
& Desember & 3 & 22.33 & & \\
\hline
\end{tabular}

Sumber : Data diolah, 2018

Berdasarkan Tabel 10 dalam uji Kruskal Wallis di atas, menunjukkan bahwa nilai signifikansi sebesar $0.674>0.05$ yang berarti bahwa Ho tidak dapat ditolak (diterima). Hal ini menjelaskan bahwa tidak terdapat perbedaan signifikan antara abnormal returnbulan Januari dengan bulan lainnya pada indeks saham LQ-45 di Bursa Efek Indonesia periode Februari 2015-Januari 2018.

Beberapa faktor penyebab terjadinya January Effect diantaranya adalah taxloss selling, window dressing dan small stock's beta. Return di bulan Januari harus dihubungkan secara positif dengan performa kerja perusahaan saat ini dan kepercayaan diri perusahaan mengenai perolehan di masa depan. Apabila korelasi positif ini tidak muncul, maka bisa dilakukan penelitian lebih lanjut mengenai karakteristik anomali (Easterday, 2015). Pada tax-loss selling seringkali sahamsaham yang mengalami tekanan jual akan mengalami penurunan harga pada bulan Desember, kemudian biasanya di bulan Januari tekanan aksi jual hilang, dan harga saham tersebut naik kembali dari harga akhir tahunnya atau akan meningkat kembali pada bulan Januari (Choudry, 2001). Namun pada penelitian ini, window dressing Desember lebih besar kemungkinan terjadinya yang menyebabkan 
Komang Intan Permatasari dan I Ketut Mustanda, Anomali Efek Kalender Pada...

adanya kenaikan return pada bulan Desember. Pada penelitian ini, rata-rata abnormal returnbulan Desember adalah 0.13272. Setiap bulan Desember, pengelola portofolio dan manajer investasi selalu memiliki kepentingan untuk mempercantik kinerja di tahun tersebut sehingga return positif justru terasa di akhir tahun.Elkhal (2004), Haug dan Hirschey (2006) serta Chou (2011) dalam penelitiannya menyebutkan bahwa terdapat perbedaan nilai premium pada perusahaan kapitalisasi besar dan perusahaan kapitalisasi kecil. Terdapat nilai premium yang lebih tinggi pada perusahaan kapitalisasi kecil di bulan Januari. Penelitian ini dilakukan pada indeks saham LQ-45 yang merupakan kumpulan perusahaan dengan kapitalisasi besar, sehingga small stock's beta tidak mempengaruhi penelitian.

Penelitian ini sejalan dengan penelitian dari Majid dan Windaswari (2015) yang menyebutkan bahwa tidak terjadi January Effect di Bursa Efek Indonesia. Penelitian dari Sari dan Sisdayani (2013) juga tidak menemukan adanya January Effectdi Bursa Efek Indonesia. Berbeda dengan kondisi pasar di Amerika dan negara luar lainnya yang memiliki perayaan Natal dan Tahun Baru secara besarbesaran, mereka cenderung menggunakan dananya bahkan menjual saham yang dimilikinya untuk merayakan hari tersebut. Penelitian dari Lobao (2018) pada pasar modal Afrika Selatan mendapatkan hasil bahwa terjadi Halloween Effect. Hasil ini mengindikasikan bahwa fenomena anomali di setiap pasar modal berbeda tergantung situasi dan kondisi di negara yang bersangkutan.

Indonesia yang mayoritas muslim dan lebih condong merayakan lebaran secara besar-besaran dibandingkan natal dan tahun baru, memiliki perilaku yang 
berbeda seperti investor di luar negeri. Ali, Akhter, dan Ashraf (2017) melakukan penelitian mengenai fenomena anomali di Pasar Modal di seluruh Asia terhadap hari raya Muslim dan mendapatkan hasil bahwa hari raya Idul Fitri memberikan hasil positif terhadap return di pasar modal. Ini bisa memberikan bukti bahwa negara mayoritas muslim seperti Indonesia, mengalami kemungkinan lebih besar mengenai terjadinya fenomena anomali pasar modal pada hari raya Idul Fitri. Bisa dilihat dari nilai mean bulan Juni dan September yang memiliki nilai positif bahkan bulan September memiliki nilai rata-rata abnormal returntertinggi yaitu 0.023045, dikarenakan bulan Juni adalah jatuhnya hari raya Idul Fitri sementara bulan September adalah jatuhnya hari raya Tahun Baru Islam.

Hasil penelitian ini menyimpulkan bahwa tidak terjadi anomali pasar bulan Januari pada 35 perusahaan sampel di indeks saham LQ-45 karena tidak ada perbedaan rata-rata abnormal returnyang signifikan pada setiap bulannya selama enam periode.

Berdasarkan penelitian ini, para investor maupun manajer keuangan tidak bisa memanfaatkan adanya momen The Day of The Week Effect, Week-Four Effect, dan January Effect dalam melakukan analisa dan pengambilan keputusan investasi terhadap portofolionya. Rata-rata abnormal return hari perdagangan, senin minggu keempat dan bulan Januari tidak memiliki perbedaan yang signifikan dan nyata terhadap waktu lainnya.

Anomali efek kalender bergantung kepada asumsi mengenai adanya suatu pola tertentu di pasar modal yang terbentuk dari harga saham yang lalu, yang bisa dijadikan acuan untuk memprediksi harga sekuritas di masa yang akan datang. 
Komang Intan Permatasari dan I Ketut Mustanda, Anomali Efek Kalender Pada...

Apabila pola tersebut sudah pasti, maka investor yang mengetahui informasi tersebut bisa memanfaatkan pola untuk mendapat keuntungan bebas risiko dengan memperjual-belikan sahamnya (Liu dan Li, 2010 ; Tevdovski, Mihajlov, dan Sazdovski, 2012).Perdagangan di bursa dipengaruhi oleh informasi yang masuk ke pasar, tetapi reaksi investor terhadap informasi tersebut bisa berubah-ubah setiap saat. Hal ini menyebabkan tidak akan ada suatu pola pasti yang bisa dimanfaatkan untuk mendapatkan keuntungan tidak wajar.

Suatu pasar dikatakan efisien apabila harga barang yang dijual telah menunjukkan semua informasi yang ada sehingga tidak bias. Bias yang dimaksud adalah penyajian informasi yang dipenuhi prasangka, sehingga harga sekuritas menjadi terlalu murah atau terlalu mahal dan tidak sesuai dengan kondisi perusahaan saat ini. Perubahan harga di masa mendatang hanya tergantung dari informasi baru di masa mendatang yang tidak diketahui sebelumnya. Perubahan harga terjadi dengan sangat cepat sehingga tidak memungkinkan untuk dieksploitasi. Sangat kecil kemungkinan seseorang untuk bisa mengalahkan dan mengelabui performa pasar secara konsisten kecuali dengan mendapatkan keberuntungan, walaupun investor menggunakan informasi yang telah diketahui pasar. Pada setiap periode, sekiranya setengah investor akan menghasilkan nilai yang memiliki performa lebih baik dari pasar dan setengahnya lagi akan mendapatkan hasil yang lebih buruk. Ada saat-saat dimana suatu pasar lebih efisien dan ada saat-saat dimana pasar menjadi kurang efisien. Saat itulah kemungkinan anomali pasar efisien terjadi sehingga investor bisa memanfaatkan keadaan tersebut untuk memperoleh lonjatkan return (abnormal return). 


\section{SIMPULAN DAN SARAN}

Berdasarkan hasil perhitungan dan pembahasan yang dilakukan, maka didapatkan kesimpulan bahwa Tidak terjadi the day of the week effect effect pada saham dalam indeks LQ-45 di Bursa Efek Indonesia selama periode Februari 2015 sampai dengan Januari 2018, Tidak terjadi week-four effect effect pada saham dalam indeks LQ-45 di Bursa Efek Indonesia selama periode Februari 2015 sampai dengan Januari 2018, Tidak terjadi January effect pada saham dalam indeks LQ-45 di Bursa Efek Indonesia selama periode Februari 2015 sampai dengan Januari 2018.

Penelitian ini tentunya masih mengandung banyak kekurangan dalampelaksanaannya, oleh sebab itu diberikan beberapa saran yaitu:Hendaknya dilakukan pengujian dengan rentang waktu yang lebih lama dan terkini, serta menggunakan indeks saham yang lebih luas contohnya indeks Kompas100, Hendaknya melakukan pengujian di berbagai corporate actions yang dilakukan oleh perusahaan seperti pengumuman stock split, pembagian dividen, size effect ataupun merger. Pengujian ini bisa dilakukan dengan menambahkan ukuran variabel untuk melihat perbedaan return dan abnormal return sehingga penelitian tidak hanya terbatas di satu variabel dan satu indeks saham saja, Selain itu kepada peneliti selanjutnya, bisa melakukan penelitian terhadap seasonal anomalies yang lain misalnya Rogalsky Effect, Monday Effect dan Holiday Effect, Untuk investor sebaiknya tidak terlalu bergantung kepada keberuntungan yang tidak tentu kapan akan tiba dalam pengambilan keputusan investasi, tetapi harus selalu memperhatikan kinerja saham perusahaan emiten dalam melakukan pengambilan 
Komang Intan Permatasari dan I Ketut Mustanda, Anomali Efek Kalender Pada...

keputusan yang tepat terhadap investasi sahamnya, baik melalui analisis teknikal maupun fundamental. Saat menjadi seorang investor, selain memiliki intuisi yang baik sangat penting untuk mampu menerima dan memiliki informasi yang berkaitan dengan tingkat harga saham. Hampir semua investasi mengandung risiko, perbedaannya hanya terletak pada besar kecilnya risiko yang akan dihadapi investor. Keadaan pasar dengan banyak orang yang berkecimpung didalamnya, membuat pasar menjadi lebih peka terhadap informasi yang masuk. Sulit bagi seorang investor untuk memperkirakan dan mengetahui dengan jelas dan akurat bagaimana sekiranya hasil yang akan didapat di masa yang akan datang, saat menanamkan dananya pada suatu saham. Maka diperlukan penilaian saham yang akurat oleh investor baik itu analisis teknikal maupun fundamental, untuk setidaknya meminimalisir risiko investasi dan selain itu pula untuk membantu investor memperoleh keuntungan yang sewajarnya saja.

\section{REFERENSI}

Ali, I., Akhter, W.,\& Ashraf, N. (2017). Impact of Muslim Holy Days on Asian stock markets:An empirical evidence. Cogent Economics \& Finance, 5(1), $1-10$.

Bachtiar, Y. (2009). Day Of The Week Effect Terhadap Return Dan Volume Perdagangan Saham LQ45 dan Non LQ45. Jurnal Keuangan dan Perbankan, 13(3), 487 - 497

Cahyaningdyah, D.,\& Witiastuti, R.S. (2010). Analisis Monday Effect dan Rogalski Effect di Bursa Efek Jakarta. Jurnal Dinamika Manajemen, 1(2), 154-168

Cahyaningdyah, D., \& Putra, D.K. (2013). Analisis January Effect Pada Saham Perusahaan LQ-45 di Bursa Efek Indonesia. Jurnal MAKSIPRENEUR, 2(2), 65-79.

Chou, J. (2011). The Value Premium and The January Effect. Managerial Finance, 37(6), 518-532. 
Choudry, T. (2001). Month of The Year Effect and January Effect in Pre-WWI Stock Returns: Evidence From a Non-Linear Garch Model. International Journal of Finance \& Economics, 6(1), 1-2

Dragota, V., Tilica, E.V.,\& Oprea, D.S. (2014). Market Efficiency, Lack of Liquidity and The Integration of Information in The Prices of Financial Assets: The Case of The Bucharest Stock Exchange.Proceedings of the 8th International Conference Accounting and Information Management Systems (AMIS), 2013(2), 347-356.

Easterday, K. (2015). The January Effect Anomaly: Effect on The ReturnsEarnings Association. American Journal of Business, 30(2), 114-115.

Elkhal, K., Shelor, R.,\& Cross, M. (2004). January Return Seasonality in The U.S. Insurance Industry.Journal of Insurance Issues, 27(2), 123-133

Fauzi, N. (2007). Analisis Fenomena Anomali Pasar January Effect dan Korelasi diantara Tiga Emerging Stock Market Asia Periode 2000-2006. Jurnal Akuntansi \& Manajemen Politeknik Negeri Padang, 2(2), 64-66

Fitriyani, I.,\&Sari, M.R.S. (2013). Analisis January Effect Pada Kelompok Saham Indeks LQ 45 Di Bursa Efek Indonesia Tahun 2009 - 2011, E-Jurnal Akuntansi Universitas Udayana, 4(2), 421 - 438

Haug, M., \& Hirschey, M. (2006). The January Effect. Financial Analysts Journal, 62(5), 78-82

Iramani, Rr.,\&Mahdi, A. (2006). Studi Tentang Pengaruh Hari Perdagangan Terhadap Return Saham Pada BEJ. Jurnal Akuntansi dan Keuangan Universitas Kristen Petra, 8(2), 66-69

Jogiyanto, H. (2010). Teori Portofolio dan Analisis Investasi(Edisi 7). Yogyakarta: BPFE Yogyakarta.

Kohli, R.K. (2014). Day-of-the-week Effect and January Effect Examined in Copper and Aluminium Metals. Journal of Business and Economics, 5(11), 1954-1955.

Latif, M., Arshad, S., Fatima, M.,\& Farooq, S. (2011). Market Efficiency ,Market Anomalies, Cause, Evidences, and Some Behavioural Aspects of Market Anomalies. Research Journal of Finance and Accounting,2(10), 2-3

Liu, B.,\&Li, B. (2010). Day-of-The-Week Effects: Another Evidence from Top 50 Australian Stocks. European Journal of Economics, Finance and Administrative Sciences, 2010(24), 78-81

Lobao, J. (2018). Are African Stock Markets Inefficient? New Evidence on Seasonal Anomalies. Scientific Annals of Economics and Business, 65(3), 283-297

Nugroho,F.S., Rahadian, D.,\& Firli, A. (2017). Pengaruh Weekday Effect dan Weekfour Effect Terhadap Return Saham Indeks LQ45 di Bursa Efek 
Komang Intan Permatasari dan I Ketut Mustanda, Anomali Efek Kalender Pada...

Indonesia Periode Februari 2007-Januari 2016. e-Proceeding of Management, 4(2), 1243-1246

Patel, N.R., Radadia, N.,\& Dhawan, J. (2012). An Empirical Study on WeakForm of Market Efficiency of Selected Asian Stock Markets. Journal of Applied Finance \& Banking, 2(2), 99-148.

Pradnyaparamita, W.,\&Rahyuda, H. (2017). Pengujian Anomali Pasar January Effect pada Perusahaan LQ45 di Bursa Efek Indonesia. E-Jurnal Manajemen Unud, 6(7), 13-19

Rita, M.R. (2009). Pengaruh Hari Perdagangan Terhadap Return Saham: Pengujian Day of the Week Effect, Week-Four Effect dan Rogalski Effect di BEI. Jurnal Ekonomi dan Bisnis, 15(2), 121-134

Roseliani, B.,\& Khairunnisa. (2015). Efek Anomali Pasar Terhadap Return Saham (Perusahaan LQ-45 yang Terdaftar di Bursa Efek Indonesia periode 2013). e-Proceeding of Management , 2(2), 1649-1657

Saraswati, Y.R., Setiorini, C.,\& Cornelia, D.A. (2015). Pengaruh The Day Of The Week Effect, Week Four Effect dan Rogalsky Effect terhadap Return Saham LQ-45 di Bursa Efek Indonesia. Jurnal Riset Akuntansi dan Perpajakan JRAP, 2(1), 43 - 54

Sari, F.A.,\& Sisdayani, S.A. (2014). Analisis January Effect di Pasar Modal Indonesia. E-Jurnal Akuntansi Universitas Udayana, 6(2). 244-247

Soares,T., Herling, L.H., Lima, M.V., \& Moritz, G. (2013). Day of The Week Effect and Stock Returns Evidence From Ibovespa. Revista de Financas Aplicados, 2(1),1-12

Tandelilin, E. (2010). Portofolio dan Investasi. Yogjakarta: Kanisius

Tevdovski, D., Mihajlov, M.,\& Sazdovski, I. (2012). The Day of The Week Effect in South Eastern Europe Stock Markets. Annals of The "Constantin Brancusi" University of Targu Jiu, Economy Series, 3(3), 20-21

Xiao, B. (2016). The Monthly Effect and The Day of The Week Effect in The American Stock Market. International Journal of Financial Research, 7(2), $11-15$ 